\title{
Assessment and comparison of quality of solar tunnel dried Bombay duck and Silver pomfret with traditional sun dried samples
}

\author{
Enamul Haque, M. Kamruzzaman, Md. Shofikul Islam, Tanvir Sarwar, \\ Shaikh Shahinur Rahman, Md. Rezaul Karim"
}

Department of Applied Nutrition and Food Technology, Islamic University, Kushtia-7003, Bangladesh

\section{Email address:}

enamanft@gmail.com(E. Haque), mkzaman.m@gmail.com(M. Kamruzzaman), shofik.anft@yahoo.com(M. S. Islam), tanvir_iu@yahoo.com(T. Sarwar), shahinanft@gmail.com(S. S. Rahman),mrkarimbio@yahoo.com(M. R. Karim)

To cite this article:

Enamul Haque, M. Kamruzzaman, Md. Shofikul Islam, Tanvir Sarwar, Shaikh. Shahinur Rahman, Md. Rezaul Karim. Assessment and Comparison of Quality of Solar Tunnel Dried Bombay Duck and Silver Pomfret with Traditional Sun Dried Samples. International Journal of Nutrition and Food Sciences. Vol. 2, No. 4, 2013, pp. 187-195. doi: 10.11648/j.ijnfs.20130204.15

\begin{abstract}
Traditional sun drying methods are widely used in Bangladesh to dry fish, though the quality is not satisfactory. The aim of this study was to assess the quality of solar tunnel dried Bombay duck and Siler pomfret, and to compare it with traditional sun dried Bombay duck and Silver pomfret. Raw fish samples of Bombay duck and Silver pomfret was collected and dried using solar tunnel dryer. The quality of the dried product was analyzed measuring moisture, protein, fat, ash, peroxide value and Total Volatile Base Nitrogen (TVB-N) content and analyzing water reconstitution properties. Traditional sun dried Bombay duck and Silver pomfret were also collected from different area, and the same measurement was also performed and compared with solar tunnel dried fish samples. Microbial quality was also analyzed using standard methods. Organoleptic quality of solar tunnel dried fish samples was found very well without any objectionable flavor and odor, compared with traditional sun dried fish samples. Moisture content was also observed (15.25\% in Bombay duck and $13.43 \%$ in Silver pomfret) within the acceptable range. Protein content of solar dried fish samples was also found higher than that of traditional sun dried samples and water reconstitution power was also found better. Peroxide and TVB-N value of the solar tunnel dried studied samples were found within the normal limit of 10$20 \mathrm{meq} / \mathrm{kg}$ of oil and up to $30 \mathrm{mg} / 100 \mathrm{gm}$, respectively. Aerobic Plate Count was found lower, however Salmonella and Coliform was not found in both dried samples. The quality of solar tunnel dried Bombay duck and Silver pomfret samples were of excellent compared with samples dried by traditional sun drying method.
\end{abstract}

Keywords: Bombay Duck, Silver Pomfret, Organoleptic Quality, Water Reconstitution Properties, Aerobic Plate Count, Solar Tunnel Dryer, Peroxide Value

\section{Introduction}

The physical and organoleptic qualities of most of the traditional sun dried products available in the market of Bangladesh are not satisfactory for human consumption due to various reasons. There are frequent complaints from the consumers about the quality of the products and the major problems associated with sun drying of fish are the infestations of the products by house fly, poor handling and sanitation, and improper processing that often lead to contamination and spoilage. One of the problems markedly evident is indiscriminate use of various types of insecticides. Sun dried fish treated with insecticides creates wide spectrum of health complications. Fish drying as a means of preservation has been practiced since the time immemorial in Bangladesh. Dry fish is also considered to add delicate flavor in the menu in many region in Bangladesh. The basic principle of fish drying is that the activity of muscle enzyme and microorganism is reduced or 
halted by reducing moisture content of fish. Fish drying is carried out in some selected coastal areas and inland depressions of Bangladesh where proper preservation facilities and good infrastructure and transport facilities are not available [1]. Sun drying of fish is carried out in the open air, using the energy of the sun to evaporate the water and air currents are used to carry away the vapor. During sun drying evaporation of water from fish is accomplished in two distinct phases [2]. In the first phase, when the surface of the fish is wet, the rate of evaporation depends on the relative humidity of air, air velocity, air temperature, and surface area of fish. In the second phase, when the entire surface moisture is carried away, drying of fish depends on the rate at which moisture can be brought to the surface of the fish, which is dependent on the nature of constituents of fish, thickness, temperature and water content [3].

Sun drying is one of the most important low-cost methods of fish preservation not only in Bangladesh but also in many areas of the world. However, around $20 \%$ of the artisanal catch is being dried by traditional sun drying methods and consumed in the domestic market [4], the quality of the dried fish are not good. In a view to improve the quality of dried fish products various types of drying methods has been developed. A Hohenheim type solar dryer developed in Germany in the early sixties were recently tested in field level in Bangladesh in order to assess its suitability in drying mangoes, pineapple and fish $[5,6]$. The quality of the dried fish produced by the Hohenheim type dryer was good in terms of organoleptic characteristics, infestation and contaminations [7,8], however, the cost of this dryer was extremely high both for small and large scale operations. Alternatively solar tunnel dryer is easy to construct with locally available material and does not require any power from electrical grid or fossil fuels. The objective of this study is to investigate the quality of solar tunnel dried fishes and to compare it with traditional sun dried fishes.

\section{Materials and Methods}

\subsection{Organoleptic Quality Assessment of Solar Dried Fish}

Sensory methods were used to assess the degree of freshness based on organoleptic characteristics such as color, odor, appearance, eyes, slime and consistency of flesh. The organoleptic quality characteristics was judged by seven panel members and the grading of fish using score on the characteristics has been followed by EC freshness grade for fishery product with slight modification $[9,10,11]$ to judge the quality of the fish.

\subsection{Proximate Analysis}

Proximate analysis of two dried fish samples, Bombay duck and Silver pomfret, dried at solar tunnel drier were done. Moreover, these two fish samples dried with traditional sun drying system were also collected from different places and proximate composition was analyzed for each collection sample. Moisture content of samples was determined according to the methods of FAO (1994) and expressed as percentage of moisture [12]. Protein content was determined by the Micro-Kjeldahl method described by AOAC [13]. Ash content was determined using a muffle furnace at $600 \pm 2{ }^{\circ} \mathrm{C}$ for $8 \mathrm{hrs}$ by $\mathrm{AOAC}$ method [14]. The total lipid in the fish was extracted using chloroform methanol phase separation and determined by the method described by Lima et al. [15]. Nutrient content on dry weight basis was calculated by dividing the reported amount of nutrient by total amount of dry matter and then the result was multiplied by 100 . Peroxide value was determined by the methods as described by Ergan et al. [16] and adopted from Wood \& Aurand [17]. Trichloro acetic acid extract was prepared as per FAO [12] and Total Volatile Base Nitrogen (TVB-N) content of the dried fish sample was determined by the micro diffusion method as described by Martin [18]. All determination was done in triplicate.

\subsection{Analysis of Water Reconstitution Behavior}

Percentage of water absorbed by dried fish at a certain temperature and time is called water reconstitution. It is one of the most important physical parameters to assess the quality of the dried products [19]. Two pieces of dried fish (20 gm each) sample were taken and weighted by analytical balance (Mettler H18) and then immerged in water at $40^{\circ} \mathrm{C}$, $60^{\circ} \mathrm{C}$ and $80^{\circ} \mathrm{C}$, respectively. The fish samples were kept under water for 60 minutes. Any loose muscle that attached to sample was removed before dipping in water. After every 15 minutes the fish sample were removed from water and the surface water was removed with blotting paper and reweighed and dipped into water of the respected beaker. The results were expressed as, $\mathrm{ml}$ of reconstitution media absorbed per $100 \mathrm{~g}$ of dried fish samples.

Calculation:

The percentage of water uptake in rehydrated fish samples was calculated as follows:

$\%$ Water reconstitution $=(\mathrm{Wr}-\mathrm{Wi}) / \mathrm{Wi}$ X 100

Initial weight of the dry fish $=\mathrm{Wi}$, Weight of dry fish after reconstitution $=\mathrm{Wr}$, Water reconstitute $=\mathrm{Wr}-\mathrm{Wi}$,

\subsection{Microbiological Analysis}

In this study, bacterial content of total aerobic plate count (APC) was performed for traditional and solar tunnel dried products of Bombay duck and Silver pomfret fish. For bacterial enumeration the US FDA [20] recommended method was followed. Aerobic plate count (APC) was performed by pour plate method using plate count agar (PCA). $1 \mathrm{ml}$ of desired dilution of sample was pipetted out and transferred aseptically to the agar plates. The sample were spread by L-shaped glass rod throughout the surface 
of the media until the sample were dried out. The plates were incubated at $30^{\circ} \mathrm{C}$ in inverted position. After $48 \mathrm{hrs}$ of incubation, the plates having 30 to 300 colonies developed were counted in order to get the cfu/g [21]. Lauryl sulphate tryptose (LST) broth was used for isolation of Escherichia coli. After incubation at $35 \pm 1^{\circ} \mathrm{C}$ for $48 \pm 2 \mathrm{hrs}$ the broth tubes that showed gas production was selected and a loopfull of the broth culture was transferred to EC broth that was further incubated at $45.5 \pm 0.2^{\circ} \mathrm{C}$ for $48 \pm 2 \mathrm{hrs}$. Gassing tube was selected for $\mathrm{E}$. coli enumeration using most probable number (MPN) method. For isolation and enumeration of Salmonella, Rappaport Vassiliadis (RV), tetrathioate (TT) broth, Hektoen enteric agar (HEA), bismuth sulphite agar (BSA) and xylose lysine desoxycholate (XLD) agar media were used [20].

\section{Results}

\subsection{Organoleptic Characteristics of Dried Fish Products}

The result of the organoleptic observation is given in Table 1. Organoleptic characteristics of the dried fish products produced from emergency solar tunnel dryer were investigated in determining color, odor, texture, insects' infestation, presence of broken pieces and overall quality. The color of solar dried Bombay duck and Silver pomfret fish became whitish to yellowish with little difference among fish species in traditional dryers. Texture was firm and flexible and color was very natural in all samples. No insects' infestation or broken pieces were found around the products. The overall quality of the products obtained from emergency solar tunnel dryer was excellent than traditional dryer for fish species.

Table 1. Organoleptic observation of traditional sun dried and solar tunnel dried fish sample collected from various places.

\begin{tabular}{|c|c|c|c|c|c|c|c|c|c|}
\hline $\begin{array}{c}\text { Dried } \\
\text { fish } \\
\text { sample }\end{array}$ & $\begin{array}{c}\text { Collection } \\
\text { source }\end{array}$ & $\begin{array}{l}\text { Storage } \\
\text { duration }\end{array}$ & $\begin{array}{c}\text { Use of } \\
\text { chemicals }\end{array}$ & Color & Odor & Texture & Infestation & $\begin{array}{l}\text { Broken } \\
\text { pieces }\end{array}$ & $\begin{array}{l}\text { Overall } \\
\text { quality }\end{array}$ \\
\hline & \multicolumn{9}{|c|}{ Dried by traditional sun drying method } \\
\hline \multirow[t]{3}{*}{$\begin{array}{l}\text { Bombay } \\
\text { duck }\end{array}$} & Kutubdia & $7-10$ days & $\begin{array}{l}\text { Nogos, } \\
\text { DDT }\end{array}$ & $\begin{array}{l}\text { Off white } \\
\text { and clear }\end{array}$ & $\begin{array}{l}\text { Characterist } \\
\text { ic odor }\end{array}$ & $\begin{array}{l}\text { Firm and } \\
\text { flexible }\end{array}$ & $\begin{array}{l}\text { No } \\
\text { infestation }\end{array}$ & Nil & Good \\
\hline & Shaparirdip & 6-7 months & Nothing & Yellowish & sour & soft & $\begin{array}{l}\text { Infested by } \\
\text { insects and } \\
\text { their eggs }\end{array}$ & Broken & Not good \\
\hline & Cox'bazar & 6-7 months & Nothing & $\begin{array}{l}\text { Brownish to } \\
\text { yellowish }\end{array}$ & sour & soft & $\begin{array}{l}\text { Infested by } \\
\text { insects }\end{array}$ & Broken & $\mathrm{Bad}$ \\
\hline \multirow[t]{3}{*}{$\begin{array}{l}\text { Silver } \\
\text { pomfret }\end{array}$} & Cox'bazar & 5-7 days & Nothing & Reddish & Natural & $\begin{array}{l}\text { Firm and } \\
\text { flexible }\end{array}$ & $\begin{array}{l}\text { No } \\
\text { infestation }\end{array}$ & Nil & Good \\
\hline & Chakti & 6-7 months & Nothing & $\begin{array}{l}\text { Brownish in } \\
\text { outer and } \\
\text { reddish in } \\
\text { inside }\end{array}$ & $\begin{array}{l}\text { Slightly } \\
\text { sour }\end{array}$ & Soft & $\begin{array}{l}\text { Slightly } \\
\text { infestation } \\
\text { by flies }\end{array}$ & $\begin{array}{l}\text { Slightly } \\
\text { broken }\end{array}$ & $\begin{array}{l}\text { Not so } \\
\text { good }\end{array}$ \\
\hline & Kazidewry & $8-9$ months & Nothing & $\begin{array}{l}\text { Brownish in } \\
\text { outer and } \\
\text { reddish in } \\
\text { inside }\end{array}$ & Sour & $\begin{array}{l}\text { Soft and } \\
\text { damp }\end{array}$ & $\begin{array}{l}\text { Infested by } \\
\text { flies and } \\
\text { insects }\end{array}$ & Broken & Very bad \\
\hline \multicolumn{10}{|c|}{ Dried by solar tunnel drier } \\
\hline $\begin{array}{l}\text { Bombay } \\
\text { duck }\end{array}$ & Cox'bazar & 1-4 days & Nothing & Whitish & $\begin{array}{l}\text { Character- } \\
\text { istic odor }\end{array}$ & $\begin{array}{l}\text { Firm and } \\
\text { flexible }\end{array}$ & Nil & Nil & Very good \\
\hline $\begin{array}{l}\text { Silver } \\
\text { pomfret }\end{array}$ & Cox'bazar & 1-4 days & Nothing & $\begin{array}{l}\text { Yellowish } \\
\text { and shining }\end{array}$ & $\begin{array}{l}\text { Character- } \\
\text { istic odor }\end{array}$ & $\begin{array}{l}\text { Firm and } \\
\text { flexible }\end{array}$ & Nil & Nil & excellent \\
\hline
\end{tabular}

The color of collected traditional sun dried fish samples were ranged from silvery to white with wide variations in different species and that of all the products were characteristics with firm and flexible texture. No broken pieces were found. The overall quality of all the products from producer source was good though the sum of the color score was not so attractive. The same products collected from wholesale market were of markedly deteriorative quality. They were stored 5 to 7 months, which lead to deterioration in color and texture compared to those of the original products. Slightly sour to sour odor was developed in many products. Infestation by flies, insects and their eggs and larvae were very common in most of them. Broken pieces were noticed some of the products. On the other hand, most of the samples from retail market were of bad quality. In contrast, the color and texture of the solar tunnel dried products were of better compared to traditional sun dried products of the same species. No broken pieces and infestation was present.

\subsection{Proximate Composition}

Proximate composition of two marine fishes and their traditional sun dried and solar tunnel dried product are 
reported in Table 2. Raw Bombay duck (88.31\%) were found to contain more moisture than Silver pomfret $(76.16 \%)$. Protein content was found more in Silver pomfret $(18.65)$ than in Bombay duck $(8.75 \%)$. Similarly, lipid (3.41\% and $1.88 \%)$ and ash (1.51\% and $0.71 \%)$ content was also found more in Silver pomfret than in Bombay duck. The moisture content of the traditional sun dried product of the two studied sample collected from different area were found in the range of $19.08 \%$ to $25.86 \%$. The protein content of traditional sun dried Silver pomfret and Bombay duck was found from $41.16 \%$ to $54.58 \%$. The range of lipid and ash content were $5.16 \%$ to $7.18 \%$ and $16.95 \%$ to $21.41 \%$, respectively.

Table 2. Proximate composition of Raw, Traditional and Solar tunnel dried fish sample

\begin{tabular}{|c|c|c|c|c|c|}
\hline Fish sample & Collection source & Moisture \% & Protein \% & Lipid \% & Ash \% \\
\hline & \multicolumn{5}{|c|}{ Raw Fish Sample } \\
\hline Bombay duck & Kutubdia & $88.31 \pm 1.63$ & $\begin{array}{c}8.75 \pm 0.42 \\
(74.85 \pm 2.83)\end{array}$ & $\begin{array}{c}1.88 \pm 0.33 \\
(16.08 \pm 2.17)\end{array}$ & $\begin{array}{c}0.71 \pm 0.01 \\
(6.07 \pm 0.59)\end{array}$ \\
\hline \multirow[t]{2}{*}{ Silver pomfret } & Shaparirdip & $76.16 \pm 1.28$ & $\begin{array}{c}18.65 \pm 0.89 \\
(78.22 \pm 3.21)\end{array}$ & $\begin{array}{c}3.14 \pm 0.59 \\
(13.17 \pm 0.78)\end{array}$ & $\begin{array}{c}1.51 \pm 0.05 \\
(6.33 \pm 0.84)\end{array}$ \\
\hline & \multicolumn{5}{|c|}{ Dried by traditional sun drying method } \\
\hline Bombay duck & Kutubdia & $21.39 \pm 1.65$ & $\begin{array}{c}50.66 \pm 2.28 \\
(66.44 \pm 2.13)\end{array}$ & $\begin{array}{c}6.24 \pm 0.39 \\
(7.93 \pm 0.61)\end{array}$ & $\begin{array}{c}18.71 \pm 1.02 \\
(23.80 \pm 1.11)\end{array}$ \\
\hline \multirow{5}{*}{ Silver pomfret } & Shaparirdip & $19.08 \pm 1.05$ & $\begin{array}{c}54.58 \pm 2.11 \\
(67.44 \pm 3.02)\end{array}$ & $\begin{array}{c}6.98 \pm 0.18 \\
(8.62 \pm 0.43)\end{array}$ & $\begin{array}{c}18.64 \pm 0.86 \\
(23.03 \pm 0.63)\end{array}$ \\
\hline & Cox'bazar & $23.61 \pm 0.87$ & $\begin{array}{c}52.49 \pm 1.69 \\
(68.71 \pm 1.31)\end{array}$ & $\begin{array}{c}5.16 \pm 0.26 \\
(6.75 \pm 0.39)\end{array}$ & $\begin{array}{c}20.32 \pm 0.92 \\
(26.60 \pm 0.67)\end{array}$ \\
\hline & Cox'bazar & $25.86 \pm 0.64$ & $\begin{array}{c}41.16 \pm 2.11 \\
(55.51 \pm 1.98)\end{array}$ & $\begin{array}{c}5.81 \pm 0.32 \\
(7.80 \pm 0.41)\end{array}$ & $\begin{array}{c}21.41 \pm 1.03 \\
(28.87 \pm 0.82)\end{array}$ \\
\hline & Chakti & $20.42 \pm 0.59$ & $\begin{array}{c}54.32 \pm 1.37 \\
(68.25 \pm 3.21)\end{array}$ & $\begin{array}{c}7.18 \pm 0.29 \\
(9.02 \pm 0.52)\end{array}$ & $\begin{array}{c}16.95 \pm 1.01 \\
(21.29 \pm 1.03)\end{array}$ \\
\hline & Kazidewry & $22.48 \pm 1.37$ & $\begin{array}{c}49.84 \pm 1.92 \\
(64.29 \pm 1.17)\end{array}$ & $\begin{array}{c}6.46 \pm 0.16 \\
(8.33 \pm 0.07)\end{array}$ & $\begin{array}{c}19.40 \pm 0.39 \\
(25.02 \pm 0.48)\end{array}$ \\
\hline Bombay duck & Cox'bazar & $15.25 \pm 0.34$ & $\begin{array}{c}\text { Dried by solar tunn } \\
68.78 \pm 3.13 \\
(81.15 \pm 2.82)\end{array}$ & rier $\begin{array}{c} \\
7.37 \pm 0.22 \\
(8.69 \pm 0.12)\end{array}$ & $\begin{array}{c}8.29 \pm 0.17 \\
(9.78 \pm 1.31)\end{array}$ \\
\hline Silver pomfret & Cox'bazar & $13.43 \pm 0.43$ & $\begin{array}{c}68.05 \pm 0.79 \\
(78.60 \pm 1.45)\end{array}$ & $\begin{array}{c}8.51 \pm 0.18 \\
(9.83 \pm 0.45)\end{array}$ & $\begin{array}{c}9.45 \pm 0.26 \\
(10.91 \pm 0.12)\end{array}$ \\
\hline
\end{tabular}

*() values indicates the result on dry weight basis.

\subsection{Water Reconstitution Behavior}

The reconstitution properties of the dried fish muscles at $40^{\circ} \mathrm{C}, 60^{\circ} \mathrm{C}$ and $80^{\circ} \mathrm{C}$ were investigated for the products obtained from both traditional sun dryer and solar tunnel dryer. The reconstitution percentages of solar tunnel dried fish produced at different temperature and time interval result are presented in Table 3 . The water holding capacity of dried fish products were shown to increase with the increase in reconstitution temperature and time. At $40^{\circ} \mathrm{C}$ after 60 minutes, traditional sun dried Bombay duck and Silver pomfret were shown to hold $41.45 \%$ and $38.76 \%$ moisture, whereas solar tunnel dried products were shown to have $61.78 \%$ and $64.14 \%$, respectively. In contrast at $80^{\circ} \mathrm{C}$ after 60 minutes, this percentage were 44.51 and 42.96, and 65.94 and 67.59 for Bombay duck and Silver pomfret of traditional Sun dried and solar tunnel dried products, respectively.

Table 3. Water reconstitution properties of traditional sun dried and solar tunnel dried fish sample.

\begin{tabular}{|c|c|c|c|}
\hline \multirow[b]{2}{*}{ Soaking Temperature } & \multirow[b]{2}{*}{ Soaking time (minutes) } & \multicolumn{2}{|c|}{ Reconstitution percentages } \\
\hline & & $\begin{array}{c}\text { \% water holding capacity } \\
\text { in Bombay duck }\end{array}$ & $\begin{array}{c}\% \text { water holding capacity } \\
\text { in Silver pomfret }\end{array}$ \\
\hline \multirow{5}{*}{$40^{\circ} \mathrm{C}$} & \multicolumn{3}{|c|}{ Traditional sun dried fish sample } \\
\hline & 15 & $19.29 \pm 1.03$ & $17.86 \pm 0.35$ \\
\hline & 30 & $28.61 \pm 0.91$ & $26.24 \pm 0.62$ \\
\hline & 45 & $36.72 \pm 1.18$ & $32.59 \pm 0.93$ \\
\hline & 60 & $41.45 \pm 2.06$ & $38.76 \pm 1.53$ \\
\hline
\end{tabular}




\begin{tabular}{llll}
\hline $60^{0} \mathrm{C}$ & 15 & $20.77 \pm 0.63$ & $18.62 \pm 0.28$ \\
& 30 & $29.98 \pm 0.97$ & $27.89 \pm 0.85$ \\
& 45 & $38.41 \pm 1.95$ & $34.14 \pm 1.17$ \\
& 60 & $43.22 \pm 1.71$ & $40.56 \pm 0.60$ \\
& 15 & $22.63 \pm 0.46$ & $20.33 \pm 0.52$ \\
& 30 & $31.25 \pm 0.29$ & $37.15 \pm 0.70$ \\
& 45 & $38.72 \pm 0.78$ & $42.69 \pm 1.37$ \\
& 60 & $44.51 \pm 1.42$ & $31.07 \pm 0.61$ \\
& & Solar tunnel dried fish sample & $42.62 \pm 0.59$ \\
& 15 & $29.30 \pm 0.52$ & $54.58 \pm 1.59$ \\
& 30 & $39.20 \pm 0.73$ & $64.14 \pm 2.06$ \\
& 45 & $52.07 \pm 0.89$ & $32.80 \pm 0.69$ \\
& 60 & $61.78 \pm 1.19$ & $43.43 \pm 1.32$ \\
& 15 & $31.33 \pm 0.73$ & $55.26 \pm 0.92$ \\
& 30 & $43.31 \pm 0.81$ & $65.20 \pm 2.56$ \\
& $30^{\circ} \mathrm{C} C$ & $54.49 \pm 1.19$ & $33.00 \pm 0.16$ \\
& 60 & $64.07 \pm 2.13$ & $46.32 \pm 0.35$ \\
\end{tabular}

\subsection{Peroxide Value and Total Volatile Base Nitrogen Content}

The peroxide values of solar tunnel dried Silver pomfret and Bombay duck were $18.62 \mathrm{meq} / \mathrm{kg}$ oil and $21.78 \mathrm{meq} / \mathrm{kg}$ oil respectively. The peroxide value of Silver pomfret was within the acceptable limit of $20 \mathrm{meq} / \mathrm{kg}$ oil [22], whereas this value for Bombay duck was not within the acceptable limit. It was also observed that peroxide value of most of the traditional sun dried product exceeded much above acceptable recommended limit. The lowest and highest value values were $16.88 \mathrm{meq} / \mathrm{kg}$ oil and $39.22 \mathrm{meq} / \mathrm{kg}$ oil for traditionally dried fish products. Total Volatile Base Nitrogen (TVB-N) content in solar tunnel dried and traditional dried product are given in Table 4 .

Table 4. Peroxide and TVB-N value of traditional sun and solar tunnel dried products.

\begin{tabular}{|c|c|c|c|}
\hline \multirow[b]{2}{*}{ Dried fish samples } & \multirow[b]{2}{*}{ Collection places } & \multicolumn{2}{|c|}{ Peroxide value (meq/kg of oil) } \\
\hline & & Traditional dried products & Solar tunnel dried products \\
\hline \multirow[t]{3}{*}{ Bombay duck } & Kutubdia & $32.50 \pm 0.89$ & \\
\hline & Shaparirdip & $39.22 \pm 1.52$ & $21.78 \pm 0.83$ \\
\hline & Cox'bazar & $19.51 \pm 1.37$ & \\
\hline \multirow[t]{4}{*}{ Silver pomfret } & Cox'bazar & $16.88 \pm 0.26$ & \\
\hline & Chakti & $28.42 \pm 2.09$ & $18.62 \pm 1.02$ \\
\hline & Kazidewry & $35.21 \pm 0.63$ & \\
\hline & & \multicolumn{2}{|c|}{ TVB-N value (mg/100g) } \\
\hline \multirow[t]{3}{*}{ Bombay duck } & Kutubdia & $28.00 \pm 0.82$ & \\
\hline & Shaparirdip & $30.24 \pm 0.59$ & $27.30 \pm 0.73$ \\
\hline & Cox'bazar & $29.15 \pm 1.03$ & \\
\hline \multirow[t]{3}{*}{ Silver pomfret } & Cox'bazar & $23.11 \pm 0.91$ & \\
\hline & Chakti & $31.05 \pm 0.39$ & $22.40 \pm 0.39$ \\
\hline & Kazidewry & $29.25 \pm 0.64$ & \\
\hline
\end{tabular}

TVB-N content of Sun dried Silver pomfret and Bombay duck sample were found $23.11 \mathrm{mg} / 100 \mathrm{~g}$ and 29.15 $\mathrm{mg} / 100 \mathrm{~g}$, respectively collected from cox'bazar area. The highest TVB-N value for both Bombay duck (30.24) and Silver pomfret (31.05) were shown to be highest in those collected from Shaparirdip and Chakti. Solar tunnel Silver pomfret (22.40) were shown to have lower TVB-N value than those of Bombay duck (27.30).

\subsection{Bacteriological Quality}

The result of Bacteriological study of raw and traditional sun and solar tunnel dried fish products are given in Table
5. Fresh fish and fishery products often have an APC of $10^{4}-10^{5} / \mathrm{g}$, although there are examples of seafoods with an APC of $10^{6}-10^{8} / \mathrm{g}$ without objectionable quality changes [23]. Aerobic plate count of raw fish sample was found $3.36 \times 10^{4}$ and $4.30 \times 10^{3} \mathrm{cfu} / \mathrm{g}$ for Bombay duck and Silver pomfret respectively, whereas no Coliform and Salmonella were found. In traditional sun dried fish sample the total aerobic bacterial count were in the range of $2.88 \times 10^{4}$ to $3.37 \times 10^{5} \mathrm{cfu} / \mathrm{g}$ for both Bombay duck and Silver pomfret collected from different region. For solar tunnel dried products, bacterial load was found lower in Bombay duck $\left(3.88 \times 10^{4} \mathrm{cfu} / \mathrm{g}\right)$ compared with Silver pomfret $\left(4.66 \times 10^{4} \mathrm{cfu} / \mathrm{g}\right)$. Salmonella and Coliform were 
found totally absent both in traditional sun dried and solar tunnel dried fish samples.

Table 5. Aerobic Plate Count (APC), Coliform and Salmonella test of Raw, Traditional sun dried and Solar tunnel dried fish sample.

\begin{tabular}{|c|c|c|c|c|}
\hline Fish sample & Collection source & APC (cfu/g) & Coliform & Salmonella \\
\hline & \multicolumn{4}{|c|}{ Raw Fish Sample } \\
\hline Bombay duck & Kutubdia & $3.36 \times 10^{4}$ & Nil & Nil \\
\hline \multirow[t]{2}{*}{ Silver pomfret } & Shaparirdip & $4.30 \times 10^{3}$ & Nil & Nil \\
\hline & \multicolumn{4}{|c|}{ Dried by traditional sun drying method } \\
\hline \multirow[t]{2}{*}{ Bombay duck } & Chakti & $6.57 \times 10^{4}$ & Nil & Nil \\
\hline & Boro Bazar & $2.88 \times 10^{4}$ & Nil & Nil \\
\hline \multirow{3}{*}{ Silver pomfret } & Cox'bazar & $1.60 \times 10^{5}$ & Nil & Nil \\
\hline & Chakti & $2.85 \times 10^{5}$ & Nil & Nil \\
\hline & Kazidewry & $3.37 \times 10^{5}$ & Nil & Nil \\
\hline & \multicolumn{4}{|c|}{ Dried by solar tunnel drier } \\
\hline Bombay duck & Cox'bazar & $3.88 \times 10^{4}$ & Nil & Nil \\
\hline Silver pomfret & Cox'bazar & $4.66 \times 10^{4}$ & Nil & Nil \\
\hline
\end{tabular}

\section{Discussion}

\subsection{Organoleptic Quality}

The organoleptic quality of traditional sun dried fish sample was found very poor comparing with solar tunnel dried products. Objectionable color, odor and texture were observed in traditional sun dried products, whereas the dried fish products from solar tunnel drier were good in all of the quality. Rahman et al. also observed attractive quality products from BFRI Fish Dryer compared to traditional sun dried products [24]. However, no discoloration was found both in traditional sun dried and solar tunnel dried products, only with insect infestation in traditional sun dried products in a study [25]. The observations of organoleptic quality in this current study was found similar with other studies with good quality products from solar tunnel dryer $[26,27,28]$.

\subsection{Proximate Composition}

The moisture content of the traditional sun dried product of the two studied sample collected from different area were found within the range of $19.08 \%$ to $25.86 \%$. The protein content of traditional sun dried Silver pomfret and Bombay duck was found from $41.16 \%$ to $54.58 \%$. The range of lipid and ash content were $5.16 \%$ to $7.18 \%$ and $16.95 \%$ to $21.41 \%$, respectively. On moisture free basis protein, lipid and ash content was found $55.51 \%$ to $68.71 \%$, $6.75 \%$ to $9.02 \%$, and $21.29 \%$ to $28.87 \%$, respectively. Highest moisture content $(25.86 \%)$ was found in Silver pomfret collected from Cox's bazar, whereas the lowest moisture content (19.08\%) was found in Bombay duck collected from Shaparirdip. The moisture content of the solar tunnel dried Bombay duck and Silver pomfret samples were $13.43 \%$ and $15.25 \%$, respectively. On the other hand, other nutrients like protein, fat and ash content were to be similar in the both tested samples.

Moisture content of solar tunnel dried products was lower than traditional sun dried products. Moisture content is a determinant of the quality of dried food products. Clucas (1982) reported that dried fish with $25 \%$ or more moisture is not sufficient to inhibit microbial growth whereas dried fish with $15 \%$ or less moisture is well enough to inhibit microbial growth [29]. Similar cutoff point was also reported by Fraizer (1978). Moisture content of solar dried Bombay duck and Silver pomfret was found below this cutoff points, whereas traditional sun dried products was not within this range [30]. Moisture content of solar tunnel dried fish samples from current studies was found lower than as studied by Reza et al. (2006) [28]. Lipid content of both traditional sun dried and solar tunnel dried products were found similar; however protein content was found higher in solar tunnel dried fish sample. Ahmed et al. (1979) also reported an increased protein and fat content in solar tunnel dried fish products compared with traditional sun dried fish products [7]. According to the study of Azimuddin et al. (2006), ash content of dried fish varied from 8.90 to $25.03 \%$ [31]. Our current study showed that ash content of solar dried fish products ranged from 8.29 to $9.45 \%$, however, this range was from 16.95 to $21.41 \%$ for traditional sun dried products.

\subsection{Water Reconstitution Properties}

The water holding capacity at different time interval was measured for both studied fish samples. It can be observed from the Table 3 that as the temperature of the soaking water increased the rate of rehydration also increased. This is might be due to the fact that increased temperature of soaking water opens the structure of fish products which favour the rapid rehydration. This is similar to the finding of Brennan et al. (1990) and Tunde-Akintunde (2008) that 
rehydration of food products depend principally on the internal structure of the dried pieces, extent to which waterholding components (e.g. protein and starch) have been damaged during drying [32,33]. Ituen et al. (1985) observed similar trend of slower rehydration rate in the later stage [34]. Roiz (1997) reported that soaking sun dried products with water for more than one hour give more tender products [35]. Our current study showed that solar tunnel dried fish samples hold more water and rehydrated more rapidly than the same fish samples dried traditionally.

\subsection{Peroxide Value and Total Volatile Base Nitrogen Content (TVB-N)}

Peroxide value of traditional sun dried fish sample were in the range of 16.88 to $39.22 \mathrm{meq} / \mathrm{kg}$ oil, whereas this values were in the range of 18.62 to $21.78 \mathrm{meq} / \mathrm{kg}$ oil for solar tunnel dried fish (Table 4). Peroxide value of Silver pomfret were in the range of 10-20 meq $/ \mathrm{kg}$ oil as suggested by Connell, however this value for Bombay duck was slightly exceed than the suggested range [36]. Peroxide value usually gives a measure of the first stage oxidative rancidity and which usually does not related with the sensory assessment of rancidity. A peroxide value of more than $20 \mathrm{meq} / \mathrm{kg}$ oil for fish usually gives bad smell and rancid taste [37]. TVB-N is usually used as a determinate of the degree of freshness of fish products during storage [38,39]. The values of TVB-N for traditional sun dried products were in the range of 23.11 to $31.05 \mathrm{mg} / 100 \mathrm{gm}$. The TVB-N value for solar tunnel dried fish sample was ranging from $22.40 \mathrm{mg} / 100 \mathrm{gm}$ in Silver pomfret and 27.30 $\mathrm{mg} / 100 \mathrm{gm}$ in Bombay duck which were within the range of acceptable limit for dried fish products [39].

\subsection{Bacteriological Quality}

Aerobic Plate Count (APC) of raw Silver pomfret and Bombay duck were in the range of $4.3 \times 10^{3}$ and $3.36 \times 10^{4}$ $\mathrm{cfu} / \mathrm{g}$. Most of the traditional sun dried fish samples were shown to have much higher APC than the raw and solar tunnel dried fish samples and the within the range of $2.88 \times 10^{4}$ to $3.37 \times 10^{5} \mathrm{cfu} / \mathrm{g}$. Aerobic Plate Count of solar tunnel dried fish samples were found similar to the finding of raw fish samples. The higher APC for traditional sun dried fish samples probably due to the fact that the higher moisture content and longer storage periods and poor hygienic condition compared with solar tunnel dried fish samples. According to Sen et al. (1961), bacterial growth is inhibited in fish samples with moisture content lower $25 \%$, whereas with less than $15 \%$ moisture content mold growth inhibited as well [39].

\section{Conclusion}

The quality aspects of two species of commercially available dried fish products were evaluated by examining the organoleptic properties, chemical composition, water reconstitution properties, peroxide value, TVB-N and bacteriological study of the samples. The organoleptic characteristics as color, odor and texture of Bombay duck and Silver pomfret dried fishes by solar tunnel drier were excellent compared with traditional sun dried fish samples. The nutritional qualities were also good as well. Moisture content of the solar dried samples was also good enough to halt microbial growth and was free from environmental dust and infestation, which is more common for traditional sun dried fish samples.

\section{Acknowledgement}

This research study was funded by the Dept. of Applied Nutrition and Food Technology Islamic University, Kushtia, Bangladesh. We are also thankful to scientist and laboratory personals of Bangladesh Fisheries Research Institute, Cox's Bazar and to the Dept. of Fisheries Technology and Dept. of Farm Power and Machinery of Bangladesh Agricultural University, Mymensing for their support providing laboratory facilities, and logistic support to carry out this research work.

\section{References}

[1] Humayun, N.M., 1985. Studies on the improvement of traditional preservation method of fish drying segment the quality and the shelf life of the product. M.Sc. Thesis. Dept. of Fisheries Technology, Bangladesh Agricultural University, Mymensingh. pp. 65.

[2] Clucas, I.J., Ward, A.R., 1996. Postharvest fisheries development: A guide to handling, preservation, processing and quality. Chatham Maritime. Kent ME4 4TB, United Kingdom.

[3] Nowsad, A.K.M., 2003. New method of drying fish in solar fish dryer. Empowerment of Coastal Fishing Community Project. Food and Agriculture Organization of the United Nations. pp. 5.

[4] Mukharjee, S., Bondyapadhya, S., Bose, A.N., 1990. An improved solar dryer for fish drying in the coastal belt. J. Food Sci. Tech. 27, 175-177.

[5] Bala, B.K., Hossain., 1998. Experimental investigation of solar drying of fish using tunnel dryer. WREC, Elsvier Science LTD.

[6] Bala, B.K., Mondal, M.R.A. 2001. Experimental investigation of solar drying of fish using tunnel dryer. Dryer Technology. 19(2), 1-10.

[7] Ahmed, S., 1979. Biochemical evaluation of the semi-drying on the composition of puti fish (Barbus puntio). M.Sc. Thesis, Dept. of Fisheries. Bangladesh Agricultural University, Mymensingh, Bangladesh.

[8] Islam, T.M., Islam, N.M., Ferdous M., 2006. Comparative feature on design, construction and installation of three different models of low cost solar tunnel dryers. Bangladesh J. Fish Res. 20(1), 51-61. 
[9] Howgate, P., Psychophysics and the Sensory Assessment of Fish. Journal of aquatic Food Product Technology, 2011, 20:2-15.

[10] Howgate, P., Johnston, A., Whittle, K.J., Multilingual guide to EC freshness grades for fishery products, Aberdeen, Scotland, UK: Torry Research Station 1992.

[11] Larmond, E., 1977. Laboratory methods for sensory evaluation of foods, Research Branch, Canadian Department of Agriculture Publication. pp. 56-59.

[12] FAO, Support to regional aquaculture activities in Latin America and the Caribbean, In: Olvera-Novoa, M. A., Martinez Palacios, C. A., and Real de Leon, E. (Eds.), Nutrition of Fish and Crustaceans- a Laboratory Manual, AB479/E, Food and Agriculture Organization of the United Nations, FAO, Mexico City 1994, pp. 61-62.

[13] AOAC, Official Methods of Analysis, 16th E.D. (Association of Analytical Chemists, Arlington, VA 1995.

[14] AOAC (Association of Official Analytical Chemists). Horwitz, N. (ed.). Official Methods of Analysis, Association of Official Analytical Chemists, $13^{\text {th }}$ ed., Washington, D. C. 1980 .

[15] Lima, D.S., James, D., Teutscher, F., 1981. Guidelines for chilled fish storage experiments, FAO, Fisheries Technical Paper. 210, 17-19.

[16] Ergan, H.R.S., Krik, Sawyer, R. 1981. Pearson's Chemical analysis of Food. $8^{\text {th }}$ ed. London. Churchill Livingston.

[17] Wood, Aurand, L.W., 1977. Laboratory manual in Food Chemistry. Avi Publishing Co. Inc. West Port. Connecticut. pp. 22-23.

[18] Martin, P. G., Manual of food quality.3. Commodities, FAO Food and Nutrition Paper, Food and Agriculture Organization of the United Nations, FAO, Rome 1979, 14(3): $175-178$.

[19] Shamima P., Kamrujjaman M., Hossain M.A., Islam M.S. Studies on the reconstitution properties of stored dried spotted spanish mackerel (Scomberomorus guttatus), International Journal of Biosciences 2011, 1(2): 27-30.

[20] US FDA. Bacterial Analytical Manual (BAM), U.S. Food \& Drug Administration Center for Food Safety \& Applied Nutrition, United States Food and Drug Administration (US FDA), Washington DC 2001. Retrieved April 2013 from http://www.911 emg.com/Ref\%20Library\%20ERG/FDA\%20 Bacteriological\%20Analysis.pdf.

[21] Rahman, M. M., Ahmed, S., Hosen, M.M., Talukder, A.K. 2012. Detection of formalin and quality characteristics of selected fish from wet markets at Sylhet city in Bangladesh. Bangladesh Research Publications Journal. 7(2), 161-169.

[22] Norziah, M.H., Nuraini, J., Lee, K.Y., 2009. Studies on the extraction and characterization of fish oil from wastes of seafood processing industry. As. J. Food Ag Ind. 2(04), 959973.

[23] Nickelson, R., Finne, G., Fish, crustaceans, and precooked seafoods. Ch. 47. In Compendium of Methods for the Microbiological Examination of Foods, 3rd ed., C.
Vanderzant and D. F. Splittstoesser (Ed.), p. 875-895. American Public Health Association, Washington, DC.

[24] Rahman, M. J., Karim, E., Uddin, M.S., Zaher, M., Haque, M.A., 2012. Development of Low-Cost Emergency Fish Dryer in Bangladesh to use in absence of sunlight. Bangladesh Research Publications Journal. 7(3), 267-276.

[25] Ojutiku, R.O., Kolo, R.J., Mohammed, M.L., 2009. Comparative Study of Sun Drying and Solar Tent Drying of Hyperopisus bebe occidentalis. Pakistan Journal of Nutrition. 8(7), 955-957.

[26] Kamal, M., Gheyasuddin, S., Chakraborty, S.C., Hossain, M.A., Faruk, M.A.R., Hossain, M.I., 1994. Development for handling, transportation and processing of high quality hilsa fish. Studies on organoleptic characteristics on the quality changes in hilsa during ice- storage. BAU. Res. Progr. 8.

[27] Faruk, M.A.R., 1995. Studies on the post-mortem changes in Rohu fish (Labeo rohita). M. Sc. Thesis, Bangladesh Agricultural University. Mymensingh. Bangladesh. pp. 47.

[28] Reza, M.S., Azimuddin, K.M., Islam, M.N., Kamal, M., 2006. Influence of Ice Storage on Raw Materials for the Production of High Quality Dried Fish Products. Journal of Biological Sciences. 6(1), 130-134.

[29] Clucas, I.J., Present fish drying techniques in Zambia and suggested improvements. A report prepared for fisheries development project. Rome, F.A.O., F.J. Zam 1982, pp. 25.

[30] Frazier, W.C., Westhoff, D.C. Microorganisms Important in Food Microbiology. Citedm Food Microbiology, Third Edition, Mc-Graw-Hill Book Company. New York 1978, pp. 539.

[31] Azimuddin, K.M., Islam, M.S., Kamal, M.A., 2006. comparative study on the nutritional quality aspects of some traditional sun dried and solar tunnel dried marine fish products. J. Bangladesh Soc. Agric. Sci. Tech. 3(1\&2), 21-24.

[32] Brennan, J.G., Butters, J.R., Cowell, N.D., Lilly, A.E.V., 1990. Dehydration in Food Engineering Operations. London: Elsevier Applied Science.

[33] Tunde-Akintunde, T.Y., Effect of Soaking Water Temperature and Time on some Rehydration Characteristics and Nutrient Loss in Dried Bell Pepper. Agricultural Engineering International: the CIGR, Ejournal. Manuscript FP 08 013. 2008, Vol. X.

[34] Ituen, E.U., Mittal, J.P., Adeoti, J.S., 1985. Water Absorption in Cereal Grains and its effect on their rupture stress. Journal of Food Process Engineering. 8:147-158.

[35] Roiz Jean-Francois, Drying Foodstuffs: Techniques, Processes, Equipment. (GERES). Leiden: Backhuys Publishers 1997.

[36] Connel, J.J., Control of fish quality. Fourth edition, Published by fishing news books, a division of Blackwell Scientific Ltd. 1995, pp. 30.

[37] Reza, M.S., Impeovedment of food quality of traditional marine dried fishery products using solar tunnel drier. M.Sc. thesis submitted to the Dept. of Fisheries Technology, Faculty of Fisheries, Bangladesh Agricultural University, Mymensing, Bangladesh 2006, pp. 136. 
[38] Cobb, B.F., Venderzont, G., 1975. Development of a chemical test for shrimp quality. J. Food Sci. 40, 121- 124.
[39] Sen, D.P., 1961. Anandaswamy, B., Iyenger, N.V.R., Lahiry, N.L., Studies on the storage characteristics and packaging of the sun-dried salted mackerel. Food Sci. 10, 148-156. 